\title{
O Poder de Polícia Sanitário e as Normas Regulamentares
}

\author{
HEALTH POLICE FORCE AND REGULAMENTATION
}

Luiz, Henrique Sormani Barbugiani(*)

A Polícia Sanitária exercida por intermédio dos órgãos integrantes do Sistema Nacional, Estadual e Municipal de Vigilância Sanitária tem, cotidianamente,

(*) Advogado Público; Especialista em Direito Sanitário pela Faculdade de Saúde Pública da Universidade de São Paulo e pela Universidade de Ribeirão Preto. E-mail: <henrluiz@yahoo.com.br>. Recebido em 21.09.06. Reapresentado em 18.06.08. Aprovado em 27.08.08. 
demonstrado a importância de sua atuação junto a diversos seguimentos de atividades de interesse à saúde pública da comunidade.

Nos dias atuais, o que seria de nós sem a intervenção da Agência Nacional de Vigilância Sanitária (ANVISA) quando, por meio de seus atos inerentes ao poder de polícia administrativo, determina a retirada do mercado de um medicamento ineficaz ou que proporcione efeitos adversos graves à saúde da população.

Os órgãos ou entidades incumbidos da fiscalização sanitária são considerados verdadeiras trincheiras numa guerra indiscriminada pela preservação da saúde e, por este motivo, merecem a devida consideração.

O legalismo exacerbado de alguns doutrinadores, entretanto, tem alimentado correntes tendentes a enfraquecer o poder de polícia sanitário, sob o argumento de que ao cidadão somente é possível impor preceitos legais em sentido estrito, jamais resoluções, portarias e outras regras de cunho normativo que não a lei propriamente dita.

Nesse contexto, decisões coerentes, como a versada na Apelação n. 245.842-5/8-00, são bem-vindas ao mundo jurídico.

O conceito de poder de polícia reflete nitidamente a necessária limitação de direitos individuais em prol do interesse público, que restaria maculado caso prevalecesse o individualismo desejado por alguns. Nessa esteira de raciocínio, surgiu a função social da propriedade e, mais recentemente, dos contratos, nos termos preconizados pelo Código Civil de 2002.

A Professora Maria Sylvia Zanella Di Pietro(1) relata a existência de um conceito clássico e outro moderno para o poder de polícia, sendo certo que, em ambos, ocorre obrigatória limitação ao exercício de direitos individuais:

Pelo conceito clássico, ligado à concepção liberal do século XVIII, o poder de polícia compreendia a atividade estatal que limitava o exercício dos direitos individuais em benefício da segurança.

Pelo conceito moderno, adotado no direito brasileiro, o poder de polícia é a atividade do Estado consistente em limitar o exercício dos direitos individuais em benefício do interesse público.

O Brasil filiou-se à corrente moderna, como salienta a autora, fato facilmente verificável pela redação constante do art. 78 do Código Tributário Nacional(2):

Art. 78. Considera-se poder de polícia atividade da administração pública que, limitando ou disciplinando direito, interesse ou liberdade, regula a prática de ato ou a abstenção de fato, em razão de interesse

(1) DI PIETRO, Maria Sylvia Zanella. Direito administrativo. 18. ed. São Paulo: Atlas, 2005. p.111.

(2) Redação dada pelo Ato Complementar n. 31, de 28.12.1966. 
público concernente à segurança, à higiene, à ordem, aos costumes, à disciplina da produção e do mercado, ao exercício de atividades econômicas dependentes de concessão ou autorização do Poder Público, à tranqüilidade pública ou ao respeito à propriedade e aos direitos individuais ou coletivos.

Não importa, realmente, na concepção da atual Constituição Federal de 1988 se as regras de limitação encontram-se especificadas apenas em lei, visto que os arts. 196 e 197 da Carta Magna deixam claro que, quanto à questão sanitária, cabe ao poder público dispor, nos termos da lei, sobre a regulamentação, fiscalização e controle de tais atividades.

Art. 196. A saúde é direito de todos e dever do Estado, garantido mediante políticas sociais e econômicas que visem à redução do risco de doença e de outros agravos e ao acesso universal e igualitário às ações e serviços para sua promoção, proteção e recuperação.

Art. 197. São de relevância pública as ações e serviços de saúde, cabendo ao poder público dispor, nos termos da lei, sobre sua regulamentação, fiscalização e controle, devendo sua execução ser feita diretamente ou através de terceiros e, também, por pessoa física ou jurídica de direito privado.

Percebe-se que a Norma Régia não exige que o ato de regulamentar, fiscalizar e controlar tais questões ocorra formalmente através de uma lei, mas sim, nos termos de uma e, por razões óbvias, respeitados os preceitos constitucionais, em especial, seus princípios.

No Acórdão objeto deste comentário, a autuação da Vigilância Sanitária ocorreu, ao que se depreende, foi embasada no art. 35 , $\S \S 4^{\circ}$ e $5^{\circ}$, da Portaria n. 344/98, que aprova o Regulamento Técnico sobre substâncias e medicamentos sujeitos a controle especial, norma que não é lei em sentido estrito, cumulada com o disposto nos arts. 57 e 122, inciso XIX da Lei Estadual n. 10.083/98, sendo oportuna a transcrição das normas nas linhas seguintes:

Portaria n. 344, de 12 de maio de 1998

Aprova o Regulamento Técnico sobre substâncias e medicamentos sujeitos a controle especial.

Art. 35. A Notificação de Receita é o documento que acompanhado de receita autoriza a dispensação de medicamentos a base de substâncias constantes das listas "A1" e "A2" (entorpecentes), "A3", "B1" e "B2" (psicotrópicas), "C2" (retinóicas para uso sistêmico) e "C3" (imunossupressoras), deste Regulamento Técnico e de suas atualizações.

...

§ 4ํ A farmácia ou drogaria somente poderá aviar ou dispensar quando todos os itens da receita e da respectiva Notificação de Receita estiverem devidamente preenchidos. 
$\S 5^{\circ}$ A Notificação de Receita será retida pela farmácia ou drogaria e a receita devolvida ao paciente devidamente carimbada, como comprovante do aviamento ou da dispensação.

$\ldots$

\section{Lei Estadual n. 10.083, de 23 de setembro de 1998}

Art. 57. Os estabelecimentos de assistência à saúde que utilizarem em seus procedimentos medicamentos ou substâncias psicotrópicas ou sob regime de controle especial, deverão manter controles e registros na forma prevista na legislação sanitária.

Art. 122. São infrações de natureza sanitária entre outras:

$X I X$ - transgredir outras normas legais federais ou estaduais, destinadas a promoção, prevenção e proteção à saúde:

Penalidade - advertência, prestação de serviços à comunidade, interdição, apreensão, inutilização, suspensão de fabricação ou venda, cancelamento de licença, proibição de propaganda, intervenção de estabelecimento de prestação de serviços de saúde e/ou multa; e

$\mathrm{Na}$ análise detida dos preceitos mencionados verifica-se que a penalidade encontra-se insculpida no art. 122, XIX, da Lei Estadual, cujo texto fala na transgressão de "outras normas legais federais e estaduais", no sentido de normas conforme a lei, ou seja, editadas pela autoridade competente.

O julgado do Tribunal de Justiça de São Paulo sub examine, por unanimidade, concluiu quanto à legalidade da lavratura do auto de infração, nos seguintes termos:

A autuação não ostenta nenhuma ilegalidade, por estarem as infrações ali apontadas, previstas de forma expressa, na legislação específica que rege a matéria ou seja na Lei Estadual Paulista n 10. 083, de 23 de setembro de 1998, que instituiu o Código Sanitário no Estado de São Paulo, em seus arts. 57 e 122, inciso X1X, e no art. 35, § 4ํ e 5 da Portaria 344/98.

A decisão do Egrégio Tribunal de Justiça de São Paulo apresenta-se de maneira incólume, uma vez que, segundo o Professor Celso Antônio Bandeira de Mello(3), o poder de polícia é exercido através de inúmeros atos, sejam eles normativos de caráter geral, como, por exemplo, a edição de Portarias, Regulamentos e Resoluções, sejam por intermédio de atos concretos e individualizados, na hipotética necessidade de interdição de um estabelecimento farmacêutico em decorrência da inobservância dos dispositivos normativos ou, ainda, em decorrência de atos de fiscalização de cunho preventivo impedindo a ação de particulares que atentem ao interesse da coletividade.

(3) MELLO, Celso Antônio Bandeira de. Curso de direito administrativo. 11 ed. São Paulo: Malheiros Ed., 1999. p. 565-566. 
Vislumbra-se, por conseguinte, que o Tribunal de Justiça de São Paulo, ao declarar a legalidade da autuação da Vigilância Sanitária, indiretamente, sabatinou o embasamento legal do ato administrativo consubstanciado no auto de infração, visto que este se utilizou não só de lei em sentido estrito, mas também de outros atos de cunho normativo, como a Portaria n. 344/98 e suas atualizações para promover o exercício do poder de polícia administrativo.

Por fim, Diógenes Gasparini(4), em sua obra, ressalta que a polícia administrativa trata de inúmeras matérias, entre elas a sanitária, representando nos setores em que ela atua o mesmo poder de polícia, mantendo-se, portanto, a unidade do instituto.

Dessa forma, conclui-se que as constatações aqui apresentadas, guardadas as devidas proporções, são aplicáveis ao instituto do poder de polícia administrativo como um todo, dado seu caráter protecionista ao interesse público sempre preponderante ao individual.

\section{REFERÊNCIAS BIBLIOGRÁFICAS}

DIÓGENES, Gasparini. Direito administrativo. 10. ed. São Paulo: Saraiva, 2005.

DI PIETRO, Maria Sylvia Zanella. Direito administrativo. 18. ed. São Paulo: Atlas, 2005.

MELLO, Celso Antônio Bandeira de. Curso de direito administrativo. 11 ed. São Paulo: Malheiros Ed., 1999.

(4) DIÓGENES, Gasparini. Direito administrativo. 10. ed. São Paulo: Saraiva, 2005. p. 128-129. 